\title{
Range extensions along western Atlantic for Epialtidae crabs (Brachyura, Majoidea) genera Acanthonyx Latreille, 1828 and Epialtus H. Milne Edwards, 1834
}

Ana Francisca Tamburus and Fernando L. Mantelatto

Laboratory of Bioecology and Crustacean Systematics (LBSC) - Postgraduate Program in Comparative Biology - Department of Biology - Faculty of Philosophy, Sciences and Letters of Ribeirão Preto (FFCLRP) - University of São Paulo (USP). Av. Bandeirantes 3900, CEP 14040901, Ribeirão Preto (SP), Brazil. E-mails: (AFT) anaftg@yahoo.com.br; (FLM) flmantel@usp.br

\section{Abstract}

\begin{abstract}
The present study provided information extending the known geographical distribution of three species of majoid crabs, the epialtids Acanthonyx dissimulatus Coelho, 1993, Epialtus bituberculatus H. Milne Edwards, 1834, and E. brasiliensis Dana, 1852. Specimens of both genera from different carcinological collections were studied by comparing morphological characters. We provide new data that extends the geographical distributions of $E$. bituberculatus to the coast of the states of Paraná and Santa Catarina (Brazil), and offer new records from Belize and Costa Rica. Epialtus brasiliensis is recorded for the first time in the state of Rio Grande do Sul (Brazil), and A. dissimulatus is reported from Quintana Roo, Mexico. The distribution of $A$. dissimulatus, previously known as endemic to Brazil, has a gap between the states of Espírito Santo and Rio de Janeiro. However, this restricted southern distribution is herein amplified by the Mexican specimens.
\end{abstract}

Key words: Geographic distribution, majoid, new records, spider crabs.

\section{Introduction}

The family Epialtidae MacLeay, 1838 includes 76 genera, among them Acanthonyx Latreille, 1828 and Epialtus H. Milne Edwards, 1834 with 17 and 11 valid species, respectively (Emparanza et al., 2007; Ng et al., 2008).

Acanthonyx dissimulatus Coelho, 1993 is a small crab known to occur from Piauí to Bahia (Coelho and Torres, 1993; Melo, 1996; Coelho et al., 2008) and São Paulo State (Mantelatto and Corrêa, 1996). It lives in shallow waters until depths of $25 \mathrm{~m}$, and can be found on hard substrates, sandy bottoms or mostly associated to aquatic vegetation
(Melo, 1996). Epialtus bituberculatus H. Milne Edwards, 1834 has been from Florida (USA), Gulf of Mexico, West Indies, Colombia, Venezuela and Brazil (Ceará to São Paulo State) (Melo, 1996); E. brasiliensis Dana, 1852 occurs in Colombia and Brazil (Ceará, Espírito Santo to Paraná State) (Fausto-Filho, 1970; Melo, 1996; Masunari and Dubiaski-Silva, 1998; Coelho et al., 2008). Both Epialtus species inhabit the intertidal zone until $10 \mathrm{~m}$ and can be frequently found associated with seagrasses (Sargassum sp.) and algae, on hard substrates or sandy bottoms (Coelho, 1971; Mantelatto and Corrêa, 1996; Melo, 1996;). Here, we provide new data that extend 
the geographical distributions of three species of epialtid crabs: Acanthonyx dissimulatus is reported from Mexico; Epialtus bituberculatus to the coast of the states of Paraná and Santa Catarina (Brazil), and offer new records from Belize and Costa Rica; and E. brasiliensis is recorded for the first time in the state of Rio Grande do Sul (Brazil).

\section{Material and Methods}

As part of a research project on the systematic of decapod crustaceans, specimens of both genera collected by us and from different carcinological collections were studied by comparing morphological characters based on Rathbun (1925, 1933), Coelho and Torres (1993), Melo (1996) and Hendrickx (1999).

The examined material was deposited in the Crustacean Collection of the Department of Biology (CCDB), Faculty of Philosophy, Sciences and Letters of Ribeirão Preto (FFCLRP), University of São Paulo (USP). Complementary specimens for analysis were obtained by loans from the following crustacean collections: Universidade Federal de Pernambuco (DOUFPE), Museu Nacional do Rio de Janeiro (MNRJ), Universidade Federal do Rio Grande do Sul (UFRGS), University of Louisiana-Lafayette, Zoological Collections (ULLZ), Universidad Nacional Autónoma de México (UNAM), and Museum of Zoology of Universidad de Costa Rica (UCR). We measured the carapace length (CL) with a vernier caliper $(0.01 \mathrm{~mm})$ in all specimens analyzed, from the posterior to the anterior margin, including the rostrum.

Results

\section{Systematics}

Section Eubrachyura Saint Laurent, 1980 Subsection Heterotremata Guinot, 1977 Infraorder Brachyura Linnaeus, 1758
Superfamily Majoidea Samouelle, 1819

Family Epialtidae MacLeay, 1838

Subfamily Epialtinae MacLeay, 1838

Acanthonyx dissimulatus Coelho, 1993

(Fig. 1A)

Material examined: MEXICO, Quintana Roo, La Mancha Rodes: 1 male (CL 15.9 $\mathrm{mm}$ ), 1 ovigerous female (CL $8.2 \mathrm{~mm}$ ), 02/ VII/2002, coll. not available (CCDB 2430).

Additional material: BRAZIL, Rio Grande do Norte, Potiguar Basin: 1 ovigerous female (CL $9.9 \mathrm{~mm}$ ), 23/XI/2003, coll. not available (DOUFPE 13837); Rio Grande do Norte, Potiguar Basin: 2 males (CL 7.1 and $10.7 \mathrm{~mm}), 23 / \mathrm{XI} / 2003$, coll. not available (DOUFPE 13906); Rio Grande do Norte, Potiguar Basin: 1 male (CL $15.4 \mathrm{~mm}$ ), 21/ XI/2003, coll. not available (DOUFPE 13920); Rio Grande do Norte, Potiguar Basin: 1 female (CL $8.6 \mathrm{~mm}$ ), 2 ovigerous females (CL 10.5 and $13.5 \mathrm{~mm}$ ), 21/XI/2003, coll. not available (DOUFPE 13927); Pernambuco, Santo Aleixo Island: 1 female (CL $8.14 \mathrm{~mm}$ ), 06/ II/2007, coll. not available (DOUFPE 13523); Pernambuco, Santo Aleixo Island: 1 ovigerous female (CL $11.5 \mathrm{~mm}$ ), 2 juveniles (CL 2.9 and $3.6 \mathrm{~mm}$ ), 06/II/2007, coll. not available (DOUFPE 13524); Bahia, Corumbau, Itacolomis: 3 males (CL $4.9-8.0 \mathrm{~mm}$ ), 16/ II/2000, coll. P.C. Paiva (MNRJ 16748); Rio de Janeiro, Arraial do Cabo, Anjos Beach: 1 male (CL $24.3 \mathrm{~mm}$ ), 1 ovigerous female (CL $20.2 \mathrm{~mm}$ ), 06/IX/2003, coll. C.E.L. Ferreira (MNRJ 19254); São Paulo, Ubatuba, Grande Beach: 1 male (CL $11.75 \mathrm{~mm}$ ), 04/V/2004, coll. F.L. Mantelatto (CCDB 1421); São Paulo, Ubatuba, Itaguá Beach: 2 males (CL 8.8 and $18.7 \mathrm{~mm}$ ), 1 female (CL $8.5 \mathrm{~mm}$ ), 2 ovigerous females (CL 17.2 and $18.5 \mathrm{~mm}$ ), 1 juvenile (CL $9.3 \mathrm{~mm}$ ), XII/1995, coll. not available (CCDB 103).

Type locality: Tambaú, João Pessoa County, Paraíba State, Brazil

Distribution: Western Atlantic: Mexico (present study) and Brazil (from Piauí to São Paulo) (Coelho and Torres, 1993; Melo, 1996; Almeida and Coelho, 2008; Coelho et al., 2008). 


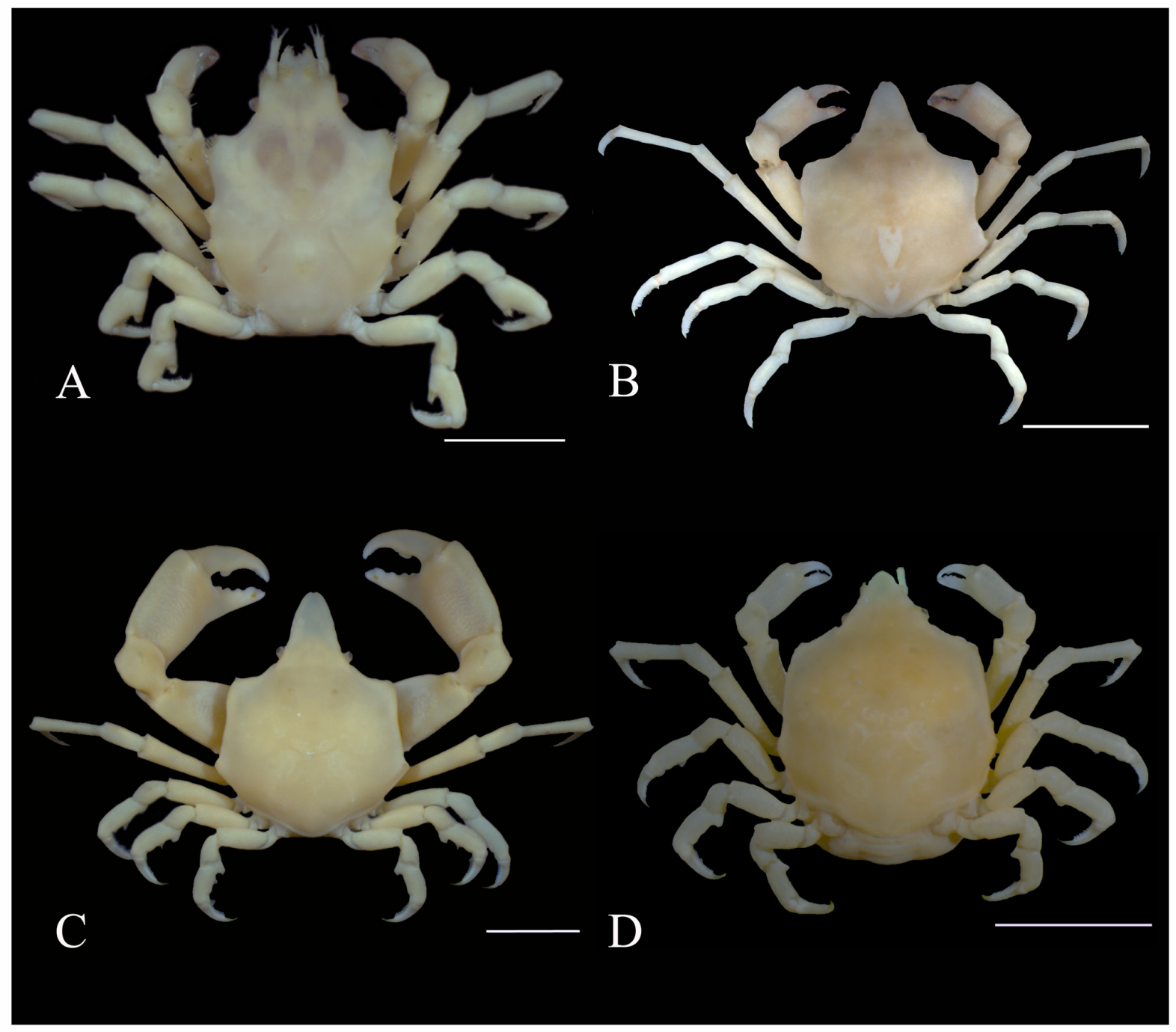

Figure 1. Dorsal view of epialtid crabs. (A) Acanthonyx dissimulatus Coelho, 1993, male CL 12.2 mm (CCDB 1421). (B) Epialtus bituberculatus H. Milne Edwards, 1834, male CL 8.9 mm (CCDB 2441). (C) Epialtus brasiliensis Dana, 1852, male CL $13.2 \mathrm{~mm}$ (CCDB 0437). (D) Epialtus brasiliensis, ovigerous female CL $9.0 \mathrm{~mm}$ (CCDB 0437). Scale bars: $5 \mathrm{~mm}$.

Remarks: The distribution of $A$. dissimulatus, previously known as endemic to Brazil (Coelho and Torres, 1993), has a gap between the states of Espírito Santo and Rio de Janeiro. However, this restricted southern distribution is herein amplified by the Mexican specimens (CCDB 2430). Furthermore, $A$. dissimulatus is very similar to $A$. petiverii $\mathrm{H}$. Milne Edwards, 1834 (Coelho and Torres, 1993), another species that also occurs in Brazil and Mexico (Retamal, 1981; Hiyodo et al., 1994; Hendrickx, 1999; Marcano and Bolaños, 2001; Emparanza et al., 2007; present study). Acanthonyx dissimulatus has not been cited from Mexico possibly because of misidentification for $A$. petiverii. In larger males of $A$. dissimulatus, the propodus of chelipeds with fingers considerably gaping when closed, and fixed finger and dactylus are smooth. In $A$. petiverii, fingers are denticulate, and the propodus of chelipeds with fingers slightly gaping when closed both in male and female (Garth, 1958; Coelho and Torres 1993; pers. obs.). Such characters are used to differentiate between the two species, although there is a lot of variation relying on the size and sex (pers. obs.). In addition, molecular analysis using different genes is under way to confirm and refine this aspect.

Epialtus bituberculatus H. Milne Edwards, 1834 (Fig. 1B) 
Material examined: BELIZE, Dondriga, Pelican Beach Resort: 1 male (CL $11.0 \mathrm{~mm}$ ), 1 female (CL $7.8 \mathrm{~mm}$ ), undated, coll. D.L. Felder (ULLZ 12624); Dondriga, Pelican Beach Resort: 1 ovigerous female (carapace damaged), 10/V/2006, coll. S. Fredericq (ULLZ 6695); COSTA RICA, Puerto Viejo: 1 male (CL $7.9 \mathrm{~mm}$ ), 2 ovigerous females (CL 7.3 and $7.4 \mathrm{~mm}$ ), 12/II/1981, coll. D. Moron (UCR 1038); BRAZIL, Paraná, Matinhos, Caiobá, Mansa Beach: 1 female (CL $4.3 \mathrm{~mm}$ ), 10/II/2002, coll. F.L. Mantelatto and E.C. Mossolin (CCDB 2263); Santa Catarina, Florianópolis, Ponta Norte, Sambaqui Beach: 1 male (CL $5.6 \mathrm{~mm}$ ), 1 ovigerous female (CL $6.7 \mathrm{~mm}), 16 / \mathrm{IV} / 2007$, coll. F.L. Mantelatto, L.G. Pileggi, L.S. Torati and E.C. Mossolin (CCDB 1887).

Additional material: MEXICO, Quintana Roo, Cozumel: 2 males (CL 9.9 and 10.9 $\mathrm{mm}$ ), 1 female (CL $6.0 \mathrm{~mm}$ ), 1 ovigerous female (CL $6.0 \mathrm{~mm}$ ), 15/I/1985, coll. J.C. Nates, J.L. Villalobos and A. Cantu (UNAM 3710); Quintana Roo, José María Morelos: 1 male (CL $5.2 \mathrm{~mm}$ ), 1 ovigerous female (CL $6.2 \mathrm{~mm}$ ), 27/I/1987, coll. not available (UNAM 21051); Quintana Roo, Solidaridad: 2 males (CL 5.7 and $12.5 \mathrm{~mm}$ ), 1 ovigerous female (CL $7.4 \mathrm{~mm}$ ), 26/VI/1988, coll. not available (UNAM 9578); PANAMA, Bocas del Toro: 1 male (CL $7.9 \mathrm{~mm}$ ), 2 females (CL 3.1 and $5.9 \mathrm{~mm}$ ), 1 ovigerous females (CL 5.9 $\mathrm{mm}$ ), 09/VIII/2004, coll. D.L. Felder (ULLZ 10755); Bocas del Toro, Playa Paunch: 1 male (CL $7.0 \mathrm{~mm}$ ), 1 female (CL $4.7 \mathrm{~mm}$ ), 05/ VIII/2011, coll. F.L. Mantelatto (CCDB 917); VENEZUELA, Isla Margarida, Boca Chica: 4 males (CL 3.1 - $7.8 \mathrm{~mm}$ ), 3 females (CL 3.8 - $6.1 \mathrm{~mm}$ ), 3 ovigerous females (CL $6.3-6.8$ $\mathrm{mm}$ ), 03/XI/2010, coll. R. Lopez (CCDB 2429); Playa Valdez: 1 ovigerous female (CL $7.6 \mathrm{~mm}), 27 / \mathrm{VIII} / 2006$, coll. F.L. Mantelatto and L.G. Pileggi (CCDB 1786). BRAZIL, Rio Grande do Norte, Potiguar Basin: 4 males (CL $5.5-6.1 \mathrm{~mm}$ ), 6 females (CL 3.9 - $6.3 \mathrm{~mm}$ ), 23/XI/2003, coll. not available (DOUFPE 13890); Rio Grande do Norte, Potiguar Basin: 1 female (CL $4.9 \mathrm{~mm}$ ), 1 ovigerous female (CL $6.0 \mathrm{~mm}$ ), 23/XI/2003, coll. not available
(DOUFPE 13899); Pernambuco, Recife, Boa Viagem Beach: 6 males (CL $5.1-12.4 \mathrm{~mm}$ ), 5 females (CL 4.7 - $5.6 \mathrm{~mm}$ ), 06/IV/2012, coll. F.L. Mantelatto (CCDB 3813); Pernambuco, Santo Aleixo Island: 2 males (CL 4.1 and $7.1 \mathrm{~mm}), 06 / \mathrm{II} / 2007$, coll. A.O. Almeida (DOUFPE 13525); Bahia, Ilhéus, Badusca Beach: 1 ovigerous female (CL $6.9 \mathrm{~mm}$ ), 06/ XI/2010, coll. F.L. Mantelatto, F.L. Carvalho and L.G. Pileggi (CCDB 2426); Rio de Janeiro, Paraty, Jurumirim Beach: 1 ovigerous female (CL $7.7 \mathrm{~mm}$ ), 24/IV/2012, coll. I.C. Leone, M. Negri and A.F. Tamburus (CCDB 3861); São Paulo, Ubatuba, Flamengo Bay: 9 males (CL 3.3 - $15 \mathrm{~mm}$ ), 7 females (CL 3.2 - $7.1 \mathrm{~mm}$ ), 2 ovigerous females (CL 8.7 and $9.4 \mathrm{~mm}), 12 / \mathrm{V} / 2010$, coll. F.L. Mantelatto (CCDB 2441); São Paulo, Ubatuba, Itaguá Beach: 1 male (CL $6.2 \mathrm{~mm}$ ), 6 females (CL 5.0 - $7.8 \mathrm{~mm}), 17 / \mathrm{II} / 2010$, coll. F.L. Mantelatto (CCDB 2431).

Type locality: Chile (?) or the Atlantic.

Distribution: Western Atlantic: Florida, Gulf of Mexico, Mexico, West Indies, Belize (present study), Costa Rica (present study), Panama (Atlantic coast) (Powers, 1977), Colombia, Venezuela, Brazil (Ceará to Santa Catarina) (Coelho, 1971; Powers, 1977; Coelho et al., 1986; Melo, 1996; HernándezAguilera et al., 1997; Marcano and Bolaños, 2001; Hernández-Ávila et al., 2007; Coelho et al., 2008; Felder et al., 2009; Lima Júnior et al., 2010; present study), and Chile (Garth, 1958).

Remarks: Epialtus bituberculatus was recorded for the first time in Chile (Milne Edwards, 1834) and that species was considered as part of the Chilean fauna for Rathbun (1925; 1933) and Abele and Kim (1986). But Garth (1958) and Powers (1977) recognized an exclusively Atlantic range, since that species was reported in the Pacific only in a single record for Milne Edwards. In the catalogue of Chilean decapods, this species was not registered (Retamal, 1981) and in Retamal and Moyano (2010) there is no occurrence yet. Thus, that record can be doubtful due to misidentification of some specimens, and other authors did not discuss this question. 
Both species of Epialtus from Brazil have similar habitat, coexisting on the same algae (Mantelatto and Corrêa, 1996; Melo, 1996; Mantelatto et al., 2004; pers. obs.), suggesting similar habits and structures. Carapace and rostrum morphology are also very similar (Rathbun, 1925; Melo, 1996), and the presence of a proximal spine on the propodus ventral surface in the last three ambulatory pereopods is the most important feature that identifies $E$. brasiliensis (with spine) and $E$. bituberculatus (spine absence).

Epialtus brasiliensis Dana, 1852 (Fig. 1C-D)

Material examined: BRAZIL, Rio Grande do Sul, Torres: 1 male (CL $13.9 \mathrm{~mm}$ ), 3 ovigerous females (CL 9.7 - $11.6 \mathrm{~mm}$ ), 08/ XII/1981, coll. not available (UFRGS 580).

Additional material: PANAMA, Bocas del Toro: 1 ovigerous female (CL $5.3 \mathrm{~mm}$ ), 09/ VIII/2004, coll. D.L. Felder (ULLZ 10755); BRAZIL, São Paulo, Ubatuba: 3 males (CL 11.8 - $12.8 \mathrm{~mm}$ ), 11 ovigerous females (CL 7.2 - $9.0 \mathrm{~mm}$ ), XII/1995, coll. F.L. Mantelatto and E.K. Correa (CCDB 437); São Paulo, Ubatuba, Itaguá Beach: 2 males (CL 9.7 and $10.8 \mathrm{~mm}$ ), 7 females (CL $6.4-7.5 \mathrm{~mm}$ ), $17 /$ II/2010, coll. F.L. Mantelatto (CCDB 2432); São Paulo, Ubatuba, Vermelha do Sul Beach: 1 male (CL $10.5 \mathrm{~mm}$ ), 1 ovigerous female (CL $8.64 \mathrm{~mm}), 30 / \mathrm{I} / 1984$, coll. F.R. Marcondes (CCDB 2433); Santa Catarina, Garopaba: 2 males (CL 7.6 and $9.5 \mathrm{~mm}$ ), 1971, coll. not available (UFRGS 034).

Type locality: Guanabara Bay, Rio de Janeiro, Brazil.

Distribution: Western Atlantic: Panama (present study), Venezuela, Colombia and Brazil (Ceará, and from Espírito Santo to Rio Grande do Sul) (Fausto-Filho, 1966; 1970; Melo et al., 1989; Melo, 1996; Masunari and Dubiaski-Silva, 1998; Marcano and Bolaños, 2001; Hernández-Ávila et al., 2007; Melo, 2008; present study).

Remarks: The material identified as E. brasiliensis (ULLZ 12624; ULLZ 6695; CCDB 1887) was examined and identified correctly as E. bituberculatus. Therefore, the extension of the geographic distribution range was possible due to these analyzes, because of the additional material (UCR 1038; UFRGS 580 ), and analyzes of our own specimens (CCDB 2430). Epialtus brasiliensis has been cited from Salvador (Gouvêa, 1986), but in northeast of Brazil this species is only known in Ceará (Fausto-Filho, 1970; Coelho et al., 2008). Thus, Almeida and Coelho (2008) considered the records from Bahia doubtful; it may be the result of insufficient sampling (Lima Júnior et al., 2010) or even mistaken for other species.

\section{Final Comments}

Following the carcinological tendency in recent years - due the increase of new projects, new collections and new groups of carcinologists - range extensions of decapod crustaceans have been recorded in many regions worldwide (Rahayu and $\mathrm{Ng}, 2000$; Tavares and Amouroux, 2003), including the Brazilian coast (e.g. Mantelatto and Dias 1999, Mantelatto et al., 2001; Cobo et al., 2002; Alves et al., 2006; Camargo et al., 2010; Almeida et al., in press). Range extensions of the epialtid crabs $A$. dissimulatus, $E$. bituberculatus and $E$. brasiliensis were relevant mainly for biogeographic and taxonomic studies.

\section{Acknowledgements}

This report is part of a Master's thesis by AFT, who was supported by a scholarship from CAPES. We are extremely grateful to Alexandre Almeida (Universidade Estadual de Santa Cruz, BA), Darryl L. Felder (University of Louisiana-Lafayette, U.S.A.), Fernando Alvarez and Jose Luis Villalobos (Universidad Nacional Autónoma de México, Mexico), Georgina Bond-Buckup (Universidade Federal do Rio Grande do Sul, RS), Ingo S. Wehrtmann (Museum of Zoology of University of Costa Rica, Costa Rica), Juan Bolaños and Carlos Lira (Universidad del Oriente, Nucleo Nueva Esparta, Venezuela), Luis E. Bezerra (Universidade Federal Rural 
do Semi-Árido, Mossoró) and Racuel Collins (Smithsonian Tropical Research Institute, Panama) for their help and for the facilities during the collections, for making available some essential fresh specimens, and for lending the material from the collections used in our research. Additional support to this project was provided by the Fundação de Amparo à Pesquisa do Estado de São Paulo - FAPESP (Biota 2010/50188-8; Coleçôes Científicas 2009/54931-0) and to FLM by CNPq (Research Grants 472746/20049, 491490/2004-6, 473050/2007-2, and 471011/2011-8; Research Scholarships PQ 301261/2004-0 and 302748/20105). The partial support and assistance of the Postgraduate Program in Comparative Biology of FFCLRP/USP; STRI for enabling FLM to travel to Panamá during the development of the course on Crustacean biology and taxonomy; members of the LBSC, during fieldwork; Ivana Miranda, Alexandre Almeida and anonymous reviewers for the revision of the text and suggestions and Julia Hetem for English revision, are gratefully acknowledged.

\section{References}

Abele, L.G. and Kim, W. 1986. An illustrated guide to the Marine decapod crustaceans of Florida. Technical Series, 8(1): 1-225.

Almeida, A.O. and Coelho, P.A. 2008. Estuarine and marine brachyuran crabs (Crustacea: Decapoda) from Bahia, Brazil: checklist and zoogeographical considerations. Latin American Journal of Aquatic Research, 36(2): 183-222.

Almeida, A.O.; Simões, S.M.; Costa, R.C. and Mantelatto, F.L. In press. Alien shrimps in evidence: new records of the genus Athanas Leach, 1814 on the coast of São Paulo, southern Brazil (Caridea: Alpheidae). Helgoland Marine Research. DOI 10.1007/ s10152-012-0291-6.

Alves, D.F.R.; Cobo, V.J. and. Melo, G.A.S.
2006. Extension of the geographical distribution of some brachyuran and porcellanid decapods (Crustacea) to the coast of the State of São Paulo, Brazil. Revista Brasileira de Zoologia, 23(4): 12801283.

Boschi, E.E. 2000. Species of decapod crustaceans and their distribution in the American marine zoogeographic provinces. Revista de Investigacion y Desarrollo Pesquero, 13: 7-136.

Camargo, F.V.; Alves, D.F.R. and Cobo, V.J. 2010. Range extensions for three majoid crabs (Crustacea, Decapoda, Brachyura) on the coast of São Paulo state, Brazil. PanAmerican Journal of Aquatic Sciences, 5(1): 169-172.

Cobo, V.J.; Pinheiro, A.P.; Freire, F.A.M. and Martins, I.A. 2002. Range extension of the geographic distribution of the lobsters (Palinuroidea) and crabs (Xanthoidea) in the Brazilian coast. Nauplius, 10(2): 155158.

Coelho, P.A. 1971. Nota prévia sobre os Majidae do Norte e Nordeste do Brasil (Crustacea: Decapoda). Arquivos do Museu Nacional Rio de Janeiro, 54: 137-143.

Coelho, P.A.; Almeida, A.O. and Bezerra, L.E.A. 2008. Checklist of the marine and estuarine Brachyura (Crustacea: Decapoda) of northern and northeastern Brazil. Zootaxa, 1956: 1-58.

Coelho, P.A.; Ramos-Porto, M. and Calado, T.C. 1986. Litoral do Rio Grande do Norte: Decapoda. Caderno Ômega da Universidade Federal de Pernambuco, Série Ciências Aquáticas, Recife, 2: 79-105.

Coelho, P.A. and Torres, M.F.A. 1993. Taxonomia e distribuição das espécies do gênero Acanthonyx Latreille, no Brasil (Crustacea: Decapoda: Majidae). Trabalhos do Instituto Oceanográfico da Universidade Federal de Pernambuco, 22: 221-241. [Dated 1991/1993, published 1993]

Emparanza, E.J.M.; Guzmán, G.L. and Ng, P.K.L. 2007. A redescription of Acanthonyx petiverii H. Milne Edwards, 1834, and designation of a neotype for Acanthonyx simplex Dana, 1852 (Brachyura, Majidae). 
Crustaceana, 80(5): 533-543.

Fausto-Filho, J. 1966. Primeira contribuição ao inventário dos crustáceos decápodos marinhos do Nordeste brasileiro. Arquivos da Estaçâo de Biologia Marinha da Universidade Federal do Ceará, 6(1): 31-37.

Fausto-Filho, J. 1970. Quarta contribuição ao inventário dos crustáceos decápodos marinhos do Nordeste brasileiro. Arquivos de Ciências do Mar, 10(1): 55-60.

Felder, D.L.; Álvarez, F.; Goy, J.W. and Lemaitre, R. 2009. Decapoda (Crustacea) of the Gulf of Mexico, with comments on the Amphionidacea. p 1019-1104. In: D.L. Felder and D.K. Camp (eds.). Gulf of Mexico Origin, Waters, and Biota - Volume 1, Biodiversity. Texas A\&M University Press, USA.

Garth, J.S. 1958. Brachyura of the Pacific coast of America; Oxyrhyncha. Allan Hancock Pacific Expedition, 21(1-2): 1-854.

Gouvêa, E.P. 1986. A carcinofauna do litoral rochoso de Salvador, BA, e alguns aspectos ecológicos. Ciência e Cultura, 38(2): 346355.

Hendrickx, M.E. 1999. Los cangrejos braquiúros (Crustacea: Brachyura: Majoidea y Parthenopoidea) del Pacifico Mexicano. Comisión Nacional para el conocimiento y uso de la biodiversidad, Instituto de Ciencias del Mar y Limnología Universidad Nacional Autónoma de México, XIV-274p.

Hernández-Aguilera, J.L.; Toral-Alamzán, R.E. and Ruíz-Nuño, J.A. 1997. Especies catalogadas de crustáceos estomatópodos y decápodos para el Golfo de México, Río Bravo, Tamaulipas a Progreso, Yucatán. Secretaría de Marina-Comisión Nacional para el Conocimiento y Uso de la Biodiversidad, México. 132p.

Hernández-Ávila, I.; Gómez, A.; Lira, C. and Galindo, L. 2007. Benthic decapod crustaceans (Crustacea: Decapoda) of Cubagua Island, Venezuela. Zootaxa, 1557: 33-45.

Hiyodo, C.M.; Fransozo, A. \& M.L. NegreirosFransozo. 1994. Larval development of the spider crab Acanthonyx petiverii H. Milne Edwards, 1834 (Decapoda, Majidae) in the laboratory. Crustaceana, 66(1): 53-66.

Lima Júnior, T.B.; Aragão, M.I.C.; Leite, J.R.S.A.; Lotufo, T.M.C. and Melo, G.A.S. 2010. Inventário dos Brachyura de substratos consolidados naturais do mesolitoral da Praia do Coqueiro, Luís Correia - Piauí. Biotemas, 23(2): 69-75.

Mantelatto F.L. and Corrêa, E.K. 1996. Composition and seasonal variations of the brachyuran crabs (Crustacea, Decapoda) living on Sargassum cymosum in the Ubatuba region, São Paulo, Brazil. Revista Bioikos, 9-10(1/2): 22-31.

Mantelatto F.L. and Dias, L.L. 1999. Extension of the known distribution of Charybdis hellerii (A. Milne Edwards, 1867) (Decapoda, Portunidae) along the western tropical South Atlantic. Crustaceana, 72(6): 617-620.

Mantelatto, F.L.; Faria, F.C.R.; Biagi, R. and Melo, G.A.S. 2004. Majoid crabs community (Crustacea: Decapoda) from infralittoral rock/sandy bottom of Anchieta Island. Brazilian Archives of Biology and Technology, 47(2): 273-279.

Mantelatto, F.L.; Garcia, R.B.; Martinelli, J.M. and Hebling, N.J. 2001. On a record of Dardanus venosus (H. Milne Edwards) (Crustacea, Anomura) from the São Paulo State, Brazil. Revista Brasileira de Zoologia, 18(1): 71-73.

Marcano, J. and Bolaños, J. 2001. Cangrejos májidos (Decapoda: Brachyura: Majidae) de las aguas someras marinas venezolanas. Boletin del Instituto Oceanografico de Venezuela, 40: 71-82.

Masunari, S. and Dubiaski-Silva, J. 1998. Crustacea Decapoda da praia rochosa da Ilha do Farol, Matinhos, Paraná. II. Distribuição espacial de densidades das populaçôes. Revista Brasileira de Zoologia, 15(3): 643-664.

Melo, G.A.S. 1996. Manual de identificação dos Brachyura (caranguejos e siris) do Litoral Brasileiro. São Paulo, Editora Plêiade/FAPESP, 604p.

Melo, G.A.S. 2008. The Brachyura (Decapoda) of Ilha Grande Bay, Rio de Janeiro, Brazil. Nauplius, 16(1): 1-22. 
Melo, G.A.S.; Veloso, V.G. and Oliveira, M.C. 1989. A fauna de Brachyura (Crustacea, Decapoda) do litoral do Estado do Paraná. Lista preliminar. Neritica, 4(1/2): 1-31.

Milne Edwards, H. 1834. Histoire naturelle des Crustacés, comprenant l'anatomie, la physiologie et la classification de ces animaux, 1: 1-468.

Ng, P.K.L.; Guinot, D. and Davie, P.J.F. 2008. Systema Brachyurorum: Part I. An annotated checklist of extant brachyuran crabs of the world. The Raffles Bulletin of Zoology, 17: 1-286.

Powers, L.W. 1977. A catalogue and bibliography to the crabs (Brachyura) of the Gulf of Mexico. Contributions in Marine Science, 20 (supplement): 1-190.

Rahayu, D.L and Ng, P.K. 2000. Some new and interesting records of spider crabs (Decapoda, Brachyura, Majidae) from Indonesia. Crustaceana, 73(7): 887-890.

Rathbun, M.J. 1925. The spider crabs of America. Bulletin of the United States National Museum, 129: 1-613.

Rathbun, M.J. 1933. Brachyuran crabs of Porto Rico and the Virgin Islands. In: Scientific Survey of Porto Rico and the Virgin Islands. New York Academy of Sciences, 15(1): 1-121. Retamal, M.A. 1981. Catalago ilustrado de los crustaceos decapodos de Chile. Editorial Universidad de Concepcion. Gayana Zoologia, 44: 1-110.

Retamal, M.A. and Moyano, H.I. 2010. Zoogeografía de los crustáceos decápodos chilenos marinos y dulceacuícolas. Latin American Journal of Aquatic Research, 38(3): 302-328.

Tavares, M. and Amouroux, J.M. 2003. First record of the non indigenous crab, Charybdis hellerii (A. Milne-Edwards, 1867) from French Guyana (Decapoda, Brachyura, Portunidae). Crustaceana, 76(5): 625-630. 